\title{
Pengembangan Alat Box Target Untuk Latihan Shooting Dalam Permainan Futsal Tahun 2020
}

\author{
Target Box Tool Development For Shooting Practice In Futsal Game 2020 \\ Rifki Alamsyah ${ }^{1}$, Dewi Endriani ${ }^{2}$ \\ ${ }^{1,2}$ Fakultas Ilmu Keolahragaan, Universitas Negeri Medan \\ Email: rifkialamsyahks@gmail.com
}

\begin{abstract}
ABSTRAK
Penelitian ini bertujuan untuk mengembangkan alat box target untuk latihan shooting dalam permainan futsal tahun 2020. Metode penelitian yang digunakan dalam penelitian ini adalah metode research and development. Populasi penilaian pada penelitian ini adalah 6 orang ahli yaitu 2 ahli olahraga, 2 ahli pelatih dan 2 ahli elektronik. Bentuk alat yang telah dibuat terlebih dahulu di validasi oleh 3 orang ahli yaitu 1 orang pelatih futsal, 1 orang akademisi olahraga yang berasal dari Universitas yang mempunyai latar belakang pendidikan olahraga, dan oleh 1 orang ahli media untuk penilaian validasi desain. Jadi, berdasarkan hasil validasi oleh para ahli maka dapat disimpulkan bahwa pengembangan box target untuk latihan shootig dalam permainan futsal tahun 2020 sudah valid dan dapat digunakan untuk latihan shooting dalam permainan futsal.
\end{abstract}

Kata Kunci: Pengembangan Alat, Futsal, Box Target

\begin{abstract}
This study aims to develop a box target tool for shooting practice in futsal games in 2020 . The research method used in this research is the research and development method. The assessment population in this study were 6 experts, namely 2 sports experts, 2 trainers and 2 electronics experts. The form of the tool that has been made in advance is validated by 3 experts, namely 1 futsal coach, 1 sports academic from the University who has a sports education background, and by 1 media expert for design validation assessment. So, based on the results of validation by experts, it can be concluded that the development of box targets for shootig practice in futsal games in 2020 is valid and can be used for shooting practice in futsal games.
\end{abstract}

Keywords: Tool Development, Futsal, Box Target

PENDAHULUAN

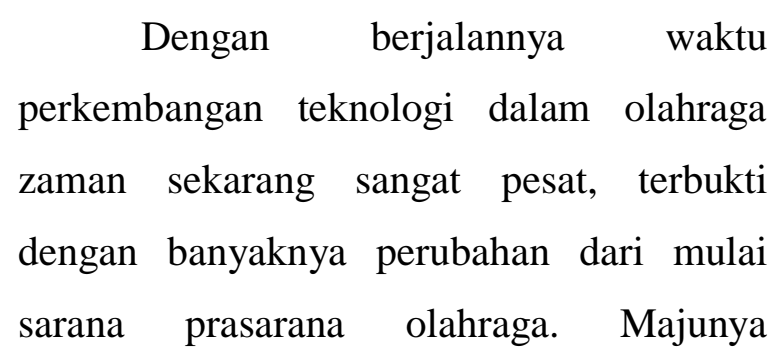

teknologi zaman sekarang tidak lepas dari orang mempunyai ide dan kreatifitas yang tinggi.

Dengan berkembangnya teknologi di era sekarang orang dengan sangat mudah mengakses berbagai macam informasi lewat 
alat elektronik maupun alat lainya pada zaman sekarang (Syakur, M. A., \& Paramitha, S. T., 2017). Berkembangnya teknologi olahraga memang sangat penting digunakan khususnya di Indonesia guna meningkatkan prestasi atlet baik lokal maupun nasional. Perkembangan dan kemajuan teknologi olahraga sangat diperlukan demi kemajuan prestasi olahraga (Jaenudin, J., Rusdiana, A., \& Kusmaedi, N. , 2018).

Shooting sangat dibutuhkan dalam permainan futsal (Buya, dkk, 2021), apalagi permainan ini harus mencetak gol sebanyak mungkin. Namun berdasarkan hasil pengamatan di Bersama FC, Pakam FC dan Surya FC bahwa peneliti melihat beberapa masalah : 1) prestasi tidak mampu mencapai skala nasional Sumatera Utara, biasanya ikut event $2 \mathrm{x}$ pertandingan sudah kalah hal ini karena ketertinggalan skor dengan lawan, 2) program latihan yang dilaksanakan tidak konsisten artinya banyak atlet yang tidak berlatih terprogram dan hanya akan berlatih rutin menjelang pertandingan, sedangkan prestasi bisa dicapai untuk puncaknya jika rutinitas latihan jangka panjang terjadi, 3) materi dalam latihan masih monoton seperti latihan biasanya, alat bantu hanya menggunakan cone saja untuk latihan fisik serta teknik, 4) kurangnya pengalaman pelatih dari segi ilmu pengetahuan serta pelatihan membuat konsep latihan tidak mampu meningkatkan kemampuan atlet.

Berdasarkan hasil wawancara pada saat observasi di tanggal 2 April 2019 bahwa banyak atlet yang menjawab belum ada latihan teknik shooting yang khusus sehingga perlu dilakukan perubahan, serta belum ada pengembangan box target sama sekali jadi hasil wawancara ini dapat dijadikan acuan bahwa kebutuhan alat box target merupakan tepat sasaran.

Box target dalam penelitian ini dibuat seukuran diameter $30 \mathrm{~cm}$ yang terbuat dari rotan dan di cat pada setiap box dengan warna yang berbeda-beda serta diberi setiap box diberi gantungan pengikat yang berfungsi sebagai penahan alat. Latihan diterapkan bebas dengan bermacam teknik. Namun shooting ke box target melalui instruksi dari pelatih yang mana akan memberikan kode sesuai warna pada alat, maka box tersebutlah yang harus menjadi target shooting atlet. Box diperkecil ukurannya dari gawang agar atlet mampu mencapai keakurasian lebih maksimal.

Peneliti melakukan analisis kebutuhan terhadap atlet dan pelatih dalam bentuk Kuesioner untuk mengetahui seberapa besar kebutuhan atlet dan pelatih di klub Bersama FC, Pakam FC dan Surya FC 
dengan latihan pengembangan alat box target untuk latihan shooting dalam permainan futsal.

Dari pengumpulan data yang telah dilakukan terhadap 20 atlet futsal diperoleh bahwa $100 \%$ memerlukan alat bantu latihan box target. $100 \%$ menyatakan alat bantu latihan box target yang digunakan selama ini tidak baik. $100 \%$ menyatakan latihan box target selama ini membosankan. 90\% mengatakan bahwa alat bantu latihan box target selama ini tidak pernah dilakukan. 100\% menyatakan latihan box target menggunakan alat/media dibutuhkan. Kemudian analisa kebutuhan terhadap 3 orang pelatih yang masih aktif melatih diperoleh $100 \%$ senang melatih futsal, $100 \%$ pelatih memerlukan alat bantu latihan box target, $100 \%$ menyatakan latihan box target selama ini kurang efektif, 90\% mengatakan bahwa alat bantu latihan box target selama ini tidak pernah dilakukan dan 100\% menyatakan latihan box target menggunakan alat/media dibutuhkan.

Dari analisis kebutuhan yang dilakukan, dapat disimpulkan bahwa ide dari penelitian pengembangan ini adalah perlu adanya pengembangan alat latihan box target dalam hal ini latihan terhadap keterampilan bermain futsal sehingga dapat membantu pelatih dalam membuat program latihan yang tujuannya untuk membuat atlet lebih berprestasi dalam akademik maupun non akademik dan bersungguh-sungguh dalam latihan shooting.

Dengan latihan shooting dibantu dengan box target peneliti yakin bahwa dapat memberikan pengaruh besar terhadap kemampuan shooting serta akurasi dan membuat keputusan yang tepat saat akan shooting. Dengan demikian maka peneliti melakukan penelitian pengembangan yang berjudul : Pengembangan Box Target Untuk Latihan Shooting Dalam Meningkatkan Permainan Futsal Tahun 2020.

\section{METODE}

Penelitian ini dilaksanakan di lapangan futsal Laut Dendang. Kecamatan Percut Sei Tuan. Kabupaten Deli Serdang. Pelaksanaan penelitian dilaksanakan pada bulan April 2020, sasaran dalam penelitian pengembangan box target terhadap latihan shooting adalah klub yang ada di Sumatera Utara. Peneliti mengambil klub yang berasal dari kabupaten deli serdang yaitu Pakam FC dengan jumlah subjek penilaian pada uji coba kecil 3 orang ahli. Dan dari Kota Madya Medan yaitu Bersama FC dan Surya FC dengan jumlah subjek penilaian pada uji coba besar sebanyak 6 orang ahli. 
Metode penelitian Dalam penelitian pengembangan box target terhadap latihan shooting pada atlet klub futsal Bersama FC, Pakam FC dan Surya FC ini merupakan suatu proses yang digunakan untuk mengembangkan dan memvalidasi produk latihan. Jenis penelitian yang digunakan adalah penelitian R\&D (Research and Development) dengan model 4D (Define, Design, Develop and Disemination). Penelitian dan pengembangan (Research and Development) bertujuan untuk menghasilakan produk baru melalui proses pengembangan.(Endang Mulyatiningsih 2013:161).

Model pengembangan perangkat Four-D Model disarankan oleh Sivasailam Thiagarajan, Dorothy S. Semmel, dan Melvyn I. Semmel (1974). Model ini terdiri dari 4 tahap pengembangan yaitu Define, Design, Develop, dan Disseminate atau diadaptasikan menjadi model 4-D, yaitu pendefinisian, perancangan, pengembangan, dan penyebarluasan (Endang Mulyatiningsih 2013:194).

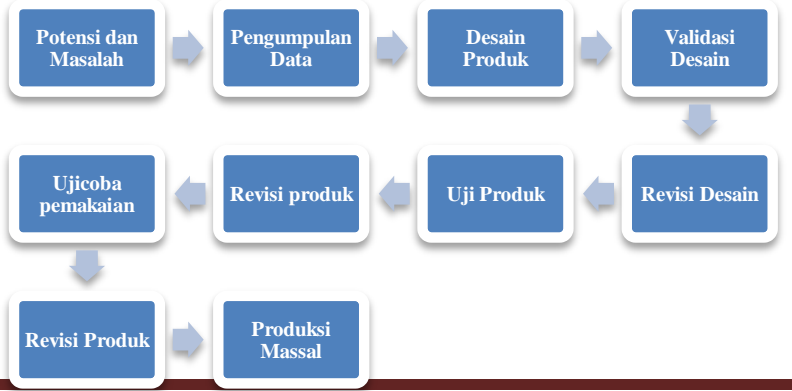

\section{Gambar 1. Langkah Penggunaan Metode Research and Development}

Adapun langkah-langkah dari desain penelitian pengembangan adalah sebagai berikut : (1) Pertama yang akan ditentukan adalah potensi dan masalah yang akan dikembangkan, (2) Mengumpulkan informasi/data sebagai landasan pemikiran untuk membuat konsep, (3) Menentukan desain produk (rancangan produk) bentuk rancangan tersebut adalah pengembangan alat box target atlet futsal, (4) Validasi desain, revisi yang dilakukan oleh ahli yang bersangkutan, (5) Perbaikan Desain, setelah direvisi oleh ahli maka peneliti memperbaiki desain produk yang akan dihasilkan, (6) Uji coba produk, uji coba tahap awal ini dilakukan untuk dapat mengumpulkan data sebagai dasar untuk menetapkan kelayakan produk, (7) Revisi produk, dilakukan untuk memperoleh hasil yang sempurna, (8) Uji coba pemakaian. Pemakaian produk yang lebih luas dan penyempurnaan produk, (9) Revisi Produk. Apabila dalam pemakaian produk dalam ujicoba yang lebih luas terdapat kelemahan revisi ini dilakukan sehingga produk lebih sempurna, (10) Pembuatan produk massal. Ini dilakukan apabila produk yang telah diujicoba 
dinyatakan efektif dan layak untuk diproduksi massal.

\section{HASIL DAN PEMBAHASAN}

Berikut adalah hasil kesimpulan persentase oleh para ahli untuk kelayakan produk.

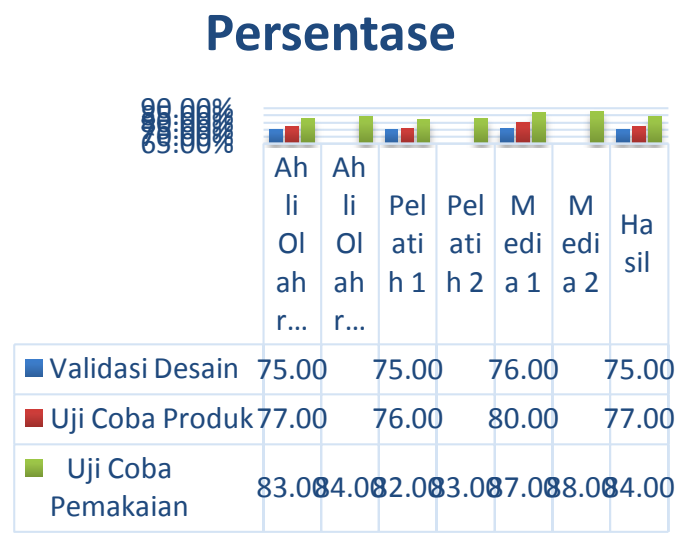

\section{Gambar 2. Grafik Kesimpulan Persentase Validasi}

Pada desain produk oleh para ahli akademisi olahraga, pelatih dan ahli elektronik memberikan nilai rata-rata persentase sebesar $75 \%$ yang berarti produk dinyatakan baik dan dapat digunakan.

Pada uji coba produk ahli akademisi olahraga, pelatih dan ahli elektronik memberikan nilai rata-rata persentase sebesar $77 \%$ yang produk dinyatakan baik dan dapat digunakan.

Pada uji coba pemakaian ahli akademisi olahraga, pelatih dan ahli elektronik memberikan nilai rata-rata persentase sebesar $84 \%$ yang berarti produk dinyatakan baik dan dapat digunakan.

Dari hasil penilaian validasi desain, uji coba produk dan uji coba pemakaian diatas maka dapat disimpulkan bahwa alat bantu latihan shooting sudah valid dan dapat digunakan dalam proses latihan untuk meningkatkan kemampuan pergerakan shooting pada atlet futsal.

Penggunaan teknologi sebagai salah satu upaya untuk meningkatkan dalam prestasi olahraga (Muarif, M., 2021) contoh saja di negara Jepang teknologinya sudah sangat maju, di Jepang ada JISS (Japan Institute of Sport Science), di Australia ada AISS (Australia Institute of Sport Science), di China ada BISS (Bejing Iinstitute of Sport Science) dan masih banyak negara mau lainya.

Futsal adalah permainan bola yang dimainkan oleh dua tim (Suryadi, dkk, 2021), yang masing-masing beranggotakan lima orang. Tujuannya adalah memasukkan bola kegawang lawan, dengan memanipulasi bola menggunakan kaki (Rosmawati, F. U., 2016). Selain lima pemain utama, setiap regu juga diizinkan memiliki pemain cadangan (Saputra, dkk, 2019). Tidak seperti permainan futsal dalam ruangan lainnya, lapangan futsal dibatasi garis, bukan net atau papan (Sasongko, G. K., 2015). 
Untuk melakukan teknik shooting ini sebenarnya mirip seperti saat kita passing akan tetapi pada shooting perlu kekuatan, power yang lebih besar sehingga menghasilkan laju bola yang cepat. Cara melakukan shooting yang benar bisa menggunakan kaki bagian dalam yang dekat dengan ujung, sisi kaki bagian luar dan dengan punggung kaki (Frayogha, J., 2019). Selain itu tembakan ke arah gawang dapat pula dilakukan dengan memakai ujung kaki pada sepatu dimana hal ini bisa menghasilkan laju bola yang cukup cepat, kencang dan arah bola tetap bergerak lurus ke depan.

\section{KESIMPULAN}

Adapun berdasarkan hasil dari validasi desain dan hasil pembahasan peneliti, maka dapat disimpulkan bahwa dengan berlatih menggunakan alat latihan akan lebih efektif dan efesien untuk dilakukan atlet futsal dan dapat memudahkan pelatih dalam menjalankan program latihan. Selain dapat melatih akurasi shooting alat ini juga bisa melatih bermain dengan menggunakan sistem menyerang. Kemudian alat ini didesain untuk dapat menarik minat atlet sehingga latihan tidak membosankan. Produk alat bantu latihan shooting ini sudah divalidasikan, ini sangat bermanfaat untuk digunakan dalam meningkatkan latihan shooting atlet.

\section{DAFTAR PUSTAKA}

Buya, P. A., Tamunu, D., \& Sumarauw, F. D. (2021). Pengaruh Latihan Permainan Target Terhadap Ketepatan Shooting Dalam Permainan Futsal. Physical: Jurnal Ilmu Kesehatan Olahraga, 2(1), 108122.

Endang Mulyatiningsih. (2013). Metode Penelitian Terapan Bidang Pendidikan. Bandung: Alfabeta.

Frayogha, J. (2019). Pengaruh Latihan Daya Ledak Otot Tungkai Terhadap Akurasi Shooting Pemain Futsal. Jurnal Patriot, 1(3), 919-931.

Jaenudin, J., Rusdiana, A., \& Kusmaedi, N. (2018). Pengembangan media latihan passing berbasis arduino uno dalam cabang olahraga futsal. Jurnal Terapan Ilmu Keolahragaan, 3(1), 47-52.

Muarif, M. (2021). Pengembangan Media Audio Visual Latihan Passing dalam Permainan Futsal: Audio Visual Media Development Passing Exercises in Futsal Games. Cerdas Sifa Pendidikan, 10(1), 16-23.

Rosmawati, F. U. (2016). Hubungan Daya Ledak Otot Tungkai Dengan Kemampuan Shooting Pemain Club Futsal Sekolah Menengah Kejuruan Nusatama

Padang. Jurnal Menssana, 1(2), 11-19.

Saputra, T. H., Supriatna, S., \& Sulistyorini, S. (2019). Meningkatkan Shooting 
Futsal Menggunakan Metode Drill. Indonesia Performance Journal, 3(2), 80-86.

Sasongko, G. K. (2015). Pengembangan Variasi Model Latihan Teknik Dasar Passing Dan Shooting Dalam Permainan Futsal Pesertasa Ekstrakurikuler Di Smp Muhammadiyah 2 Malang. Jurnal Sport Science, 5(1), 31-46.

Suryadi, O. R., Maulana, F., \& Saputri, H. (2021). Pengaruh Permainan Target Terhadap Akurasi Shooting Pada Permainan Futsal dalam ektrakurikuler SMAN 2 Kota Sukabumi. Riyadhoh: Jurnal Pendidikan Olahraga, 4(1), 88-90.

Syakur, M. A., \& Paramitha, S. T. (2017). Pengembangan Alat Bantu Latihan Pelontar Bola Futsal Berbasis Mikrokontroler Dengan Menggunakan Software Pemograman Arduino. JTIKOR (Jurnal Terapan Ilmu Keolahragaan), 2(1), 29-32.

Thiagarajan Sivasailam, Dorothy S. Semmel dan Melvyn I. Semmel. (1974). Instructional Development for Training Teachers of Exceptional Children. Bloomington: Indiana University. 